\title{
Pengaruh Kepemimpinan dan Supervisi Akademik Kepala Sekolah Terhadap Disiplin Kerja Guru di SMP Negeri 3 Harian
}

\author{
Mujur Nadeak ${ }^{1^{*}}$ \\ 1SMP Negeri 3 Harian, Indonesia \\ *Korespondensi: nadeakmujur@gmail.com
}

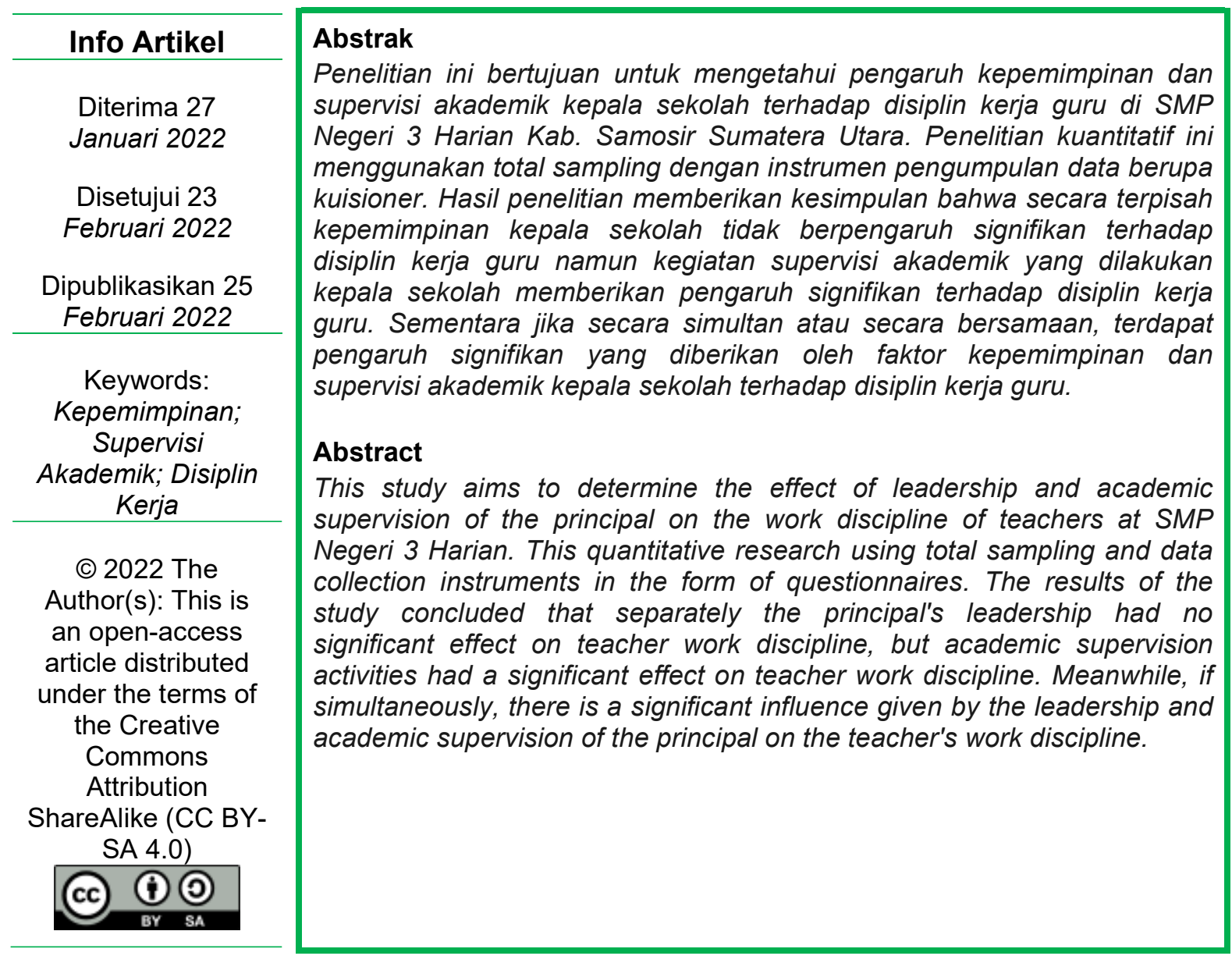

\section{Pendahuluan}

Sekolah merupakan organisasi pendidikan formal, dengan guru sebagai salah satu unsur utama didalamnya. Guru yang bermutu akan memberikan dampak signifikan bagi mutu sekolah tersebut. Peran utama guru di sekolah adalah memastikan agar proses pendidikan dan pembelajaran dapat berjalan dengan baik dan benar. Untuk itu tentunya diperlukan guru-guru berkualitas, loyal dan disiplin kerja yang tinggi. Disiplin tinggi yang dimiliki seorang guru akan sangat berdampak pada upaya pencapaian tujuan pendidikan sekolah (Purwanti, 2013). 
Disiplin kerja merupakan suatu sikap atau perilaku menaati peraturan yang ditetapkan pada suatu organisasi kerja (Alhusaini et al., 2020). Pengertian disiplin sebagaimana diuraikan dalam PP No. 53 Tahun 2010 sebaga sikap atau perilaku seseorang dalam melaksanakan kewajiban serta tidak melanggar aturan sesuai peraturan yang ada. Dengan memandang guru sebagai bagian komponen SDM, tentu tingkat kedisiplinan guru di tempat bekerja menjadi faktor yang sangat berpengaruh dalam menentukan keberhasilan kinerja guru tersebut dalam menjalankan peranannya di sekolah (Hadiati, 2018).

Terdapat beberapa masalah yang muncul di dunia pendidikan khususnya disekolah terkait disiplin kerja guru. Dalam penelitian (Alhusaini et al., 2020) diurikan beberapa masalah disiplin guru antara lain kedatangan guru yang masih terlambat, bolos saat jam mengajar, tidak segera melaksanakan tugas, pulang lebih cepat dari waktu seharusnya, dan sebagainya. Masalah lain terkait disiplin kerja guru diuraikan dalam penelitian (Abd. Rahman, 2014) antara lain ada guru yang tidak maksimal dalam menyusun rpp sehingga penyampaian materi tidak maksimal. Selain itu ada juga guru yang belum melaksanakan evaluasi dengan benar mapun tidak memeriksa hasil evaluasi belajar siswa.

Mutu rendah pendidikan sekolah turut disebabkan oleh rendahnya disiplin kerja guru (Nugraheni \& Rahmayanti, 2016). Untuk itu diperlukan usaha menangani rendahnya disiplin kerja guru di lingkungan pendidikan khususnya di sekolah. Penegakan disiplin kerja guru tersebut memerlukan adanya seorang pemimpin yaitu kepala sekolah yang benar-benar mampu melaksanakan tanggungjawabnya dalam memimpin manajemen sekolah. Kepala sekolah memegang peranan utama dalam menentukan arah dalam mencapai tujuan pendidikan, salah satunya melalui penegakan disiplin kerja guru (Rusmawati, 2013). Kepala sekolah merupakan pimpinan dalam satu organisasi sekolah. Kepala sekolah berperan dan menanggungjawabi setiap upaya tercapainya tujuan pendidikan di sekolah (Rusmawati, 2013). Efektifnya seorangg kepala sekolag dalam memimpin merupakan salah satu faktor terpenuhinya target kualitas pendidikan (Ekosiswoyo, 2007).

Peran kepemimpinan dapat dikatakan sebagai sikap atau perilaku pemimpin agar anggota berusaha dengan maksimal berupaya mencapai tujuan yang telah ditentukan organisasi (Nurfarhana et al., 2017 ; Purwanti, 2013). Keberhasilan sekolah dalam mencapai tujuan merupakan salah satu indikator berhasilnya seorang kepala sekolah dalam kepemimpinannya (Tiswarni, 2019). Dengan demikian usaha kepala sekolah untuk mempengaruhi pada guru di lingkungan sekolah agar memiliki disiplin kerja yang maksimal merupakan kepemimpinan kepala sekolah.

Pembahasan mengenai definisi kepemimpinan, baik secara umum termasuk kepemimpinan dalam bidang dunia pendidikan setidaknya memiliki dua hal utama (Ekosiswoyo, 2007) yakni (1) definisi kepemimpinan sebagai suatu ilmu atau seni untuk mempengaruhi orang lain dalam meraih sasaran target, dan (2) untuk mempengaruhi atau menggerakkan orang lain tersebut, pemimpin yang dimaksud harus memiliki sifat menghargai dan menghormati perbedaan yang ada untuk kemudian berusaha menciptakan kekuatan. Menurut (Purwanti, 2013) ketika seorang kepala sekolah di suatu institusi sekolah dipercaya untuk menjadi pemimpin, kepala sekolah tersebut harus mempunyai kemampuan dan juga keahlian-keahlian untuk menopang tanggungjawabnya sebagai seorang pemimpin. 
Kemampuan tersebut antara lain berupa kemampuan komunikasi yang dapat diandalkan, kemampuan menjalankan fungsinya sebagai kepala sekolah secara teknis dalam bidangnya, kemampuan melakukan evaluasi atau analisis yang mendalam dan tajam, memiliki kemampuan untuk menunjukkan ketegasan dan keberanian ketika memilih dan menentukan keputusan, memiliki semangat kerja maksimal serta visi rinci dan jelas.

Prinsip kepemimpinan yang harus dimiliki seorang kepala sekolah juga merupakan hal yang perlu untuk dikuasai dan dilaksanakan dalam tugas dan tanggungjawabnya. Prinsip-prinsip seorang kepala sekolah dalam menjalankan tugasnya diantaranya bersifar membangun atau konstruktif, memiliki nilai kreativitas, berpartisipatif, mampu bekerjasama atau kooperatif, mempercayai tim dalam menjalankan tugas atau delegatif, integratif, mampu berpikir dan bertindak rasional, serta memiliki sudut pandang yang objektif (Purwanti, 2013).

Membina guru dalam kedisiplinan mereka termasuk salah satu tugas kepala sekolah sebagai pemimpin organisasi sekolah, dimana sikap disiplin harus ditanamkan secara konsisten karena pentingnya disiplin tersebut berdampak bagi guru (Yuliandri \& Kristiawan, 2016). Menurut (Ekosiswoyo, 2007) terdapat tujuh hal penting sebagai landasan Kepala Sekolah dalam memimpin sekolahnya, yakni (1) seorang kepala sekolah tidak bersikap menunggu, namun harus aktif memulai dan mencapai target sedini mungkin, (2) Kepala sekolah harus mempunyai karakter yang berbobot dan memiliki kredibilitas, (3) Kepala Sekolah selain harus mempunyai kesadaran visi, misi dan tujuan dalam melihat ke depan (visioner), juga harus mampu membumi, menyayomi, serta dapat dibanggakan, (4) Memiliki harpaan yang sama atau sesuai dengan para bawahan atau orang yang dipimpinnya, (5) Kepala Sekolah harus berkolaborasi dengan mengutamakan kebersamaan dan tidak egois, (6) Kepala Sekolah harus mewariskan pola atau guide kepemimpinan yang terbaik untuk kepentingan bersama, serta (7) Kepala sekolah dalam memimpin harus berdasarkan kepentingan atau kebutuhan bersama, dimana pendapat yang diberikan setiap orang bernilai sama dan layak dihargai sama.

Diperlukan aturan atau norma pendukung dalam menjalankan prinsip kepemimpinan antara lain memiliki wibawa, memiliki kejujuran, bersikap adil, benar, bisa dipercaya, mengayomi, berani, mawas diri, memiliki visi yang jelas, menghormati dan menghargai hak orang lain, sesuai dengan aturan azas hukum, mengabdi pada tanggung jawab yang ditugaskan, berjiwa besar, serta memiliki rasa ingin tahu yang berfokus pada kemajuan. Prinsip kepemimpinan seorang kepala sekolah dilaksanakan dan ditanggungjawabi dengan baik karena memiliki pengaruh terhadap kualitas pendidikan dan juga disiplin, produktivitas kerja dan kinerja guru(Rusmawati, 2013). Dengan berbagai pemikian tersebut maka diduga disiplin kerja guru dipengaruhi oleh faktor kepemimpinan seorang kepala sekolah.

Terdapat lima gaya seorang kepala sekolah dalam memimpin dan mengelola sekolah yaitu "kepemimpinan manajerial, kepemimpinan transformasional, kepemimpinan transaksional, kepemimpinan pengajaran, dan kepemimpinan positif" (Lumban Gaol, 2017). Lebih lanjut (Lumban Gaol, 2017) menjelaskan dalam artikelnya bahwa penerapan gaya-gaya kepemimpinan tersebut dapat dilakukan seperti: (1) secara efektif dan efisien dalam menyusun konsep program sekolah, (2) berdampak yang signifikan terhadap setiap warga sekolah maupun stakeholder, (3) meningkatkan profesionalisme guru serta staf kependidikan, (4) 
membangun kondisi yang kondusif untuk proses pembelajaran maupun iklim sekolah, serta (5) dalam pengelolaan sekolah senantiasa memiliki persepsi yang positif.

Menurut riset yang dilakukan (Nasution \& Ichsan, 2020), gaya kepemimpinan seorang kepala sekolah secara signifikan berkaitan dengan kinerja guru sebesar $56,9 \%$. Artinya bahwa gaya kepemimpinan yang semakin baik meningkatkan kinerja guru. Sejalan dengan itu penelitian (Said, 2018) mengemukakan bahwa bagaimana seorang kepala sekolah memimpin turut memberikan dampak pada proses pendidikan berjalan, pembinaan guru, serta mutu sekolah. Juga penelitian (Salim, 2016) menyimpulkan dampak positif yang diberikan oleh pola kepemimpinan Kepala Sekolah atas disiplin kerja guru. Dari uraian yang telah dijabarkan diatas maka peneliti menduga kepemimpinan seorang kepala sekolah berpengaruh pada disiplin kerja guru SMPN 3 Harian.

Selain faktor kepemimpinan, kegiatan supervisi akademik juga dapat dianggap sebagai usaha kepala sekolah untuk meningkatkan kinerja guru (Suginam, 2019). Supervisi akademik secara umum merupakan "layanan professional yang diberikan dalam rangka meningkatkan profesionalisme guru dalam melaksanakan tugas pokoknya sebagai pendidik dan pengajar" (Sola, 2019). Dalam pelaksanaan tugas guru di sekolah, maka tentu saja yang memberikan layanan supervisi akademik adalah kepala sekolah. Supervisi akademik merupakan salah satu kemampuan yang harus dimiliki seorang kepala sekolah, sebagaimana diuraikan dalam Permendiknas RI Nomor 13 Tahun 2007.

Dalam tugasnya sebagai seorang pemimpin, kepala sekolah harus memiliki kompetensi dan memahami konsep supervisi akademik, antara lain mampu menjabarkan definisi supervisi akademik, tujuan dilakukannya supervisi akademik, aturan dan kaidah supervisi akademik, serta dimensi substansi supervisi akademik (Prayoga, 2020). Kepala sekolah juga perlu merancang, melaksanakan, mengevaluasi secara terstruktur berkesinambungan atas kegiatan supervisi yang dilakukan agar kompetensi guru dapat meningkat khususnya dalam proses pembelajaran, baik pedagogis, profesionalitas, pribadi, dan aspek sosial (Sola, 2019). Sebagaimana diuraikan dalam artikel (Suhayati, 2013) yang menggambarkan korelasi antara kegiatan supervisi akademik, proses mengajar guru serta hasil pembelajaran sebagai berikut:

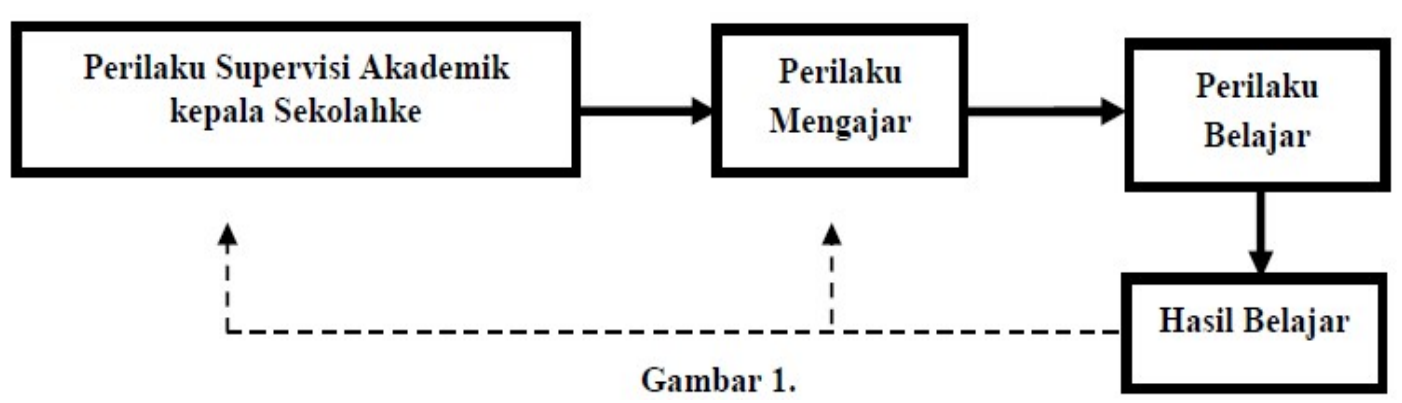

Gambar 1. Korelasi supervisi, proses mengajar dan hasil pembelajaran.

Dalam melaksanakan supervisi akademik, peneliti merumuskan kegiatan supervisi pendidikan dalam 3 tahapan kegiatan (Prayoga, 2020) yaitu tahapan kepala sekolah menyusun rancangan pelaksanaan supervisi akademik; taapan proses melaksanakan kegiatan supervisi akademik; dan tahapan refleksi-evaluasi supervisi akademik kepala sekolah. Kegiatan menyusun rancangan pelaksanaan 
supervisi akademik terdiri dari dua tahapan yakni tahap menyusun program supervisi (prota dan prosem), dan tahap persiapan misalnya menyusun instrument kegiatan supervisi, bahan supervisi, buku deskripsi kegiatan supervisi, dan schedule pelaksanaan supervisi akademik. Pelaksanaan supervisi akademik berfokus pada target supervisi, yakni langkah atau prosedur, seperti aksi, pengamatan, dan refleksi. Kegiatan supervisi akademik tentu berdasar pada masalah problematika yang dialami guru. Selanjutnya tahapan terakhir adalah melakukan tindak lanjut hasil yang diperoleh dari kegiatan supervisi sehingga memberikan pengaruh dalam peningkatan profesionalisme tenaga pendidik, dilakukan dengan cara memberikan umpan balik atas hasil supervisi akademik tersebut kepada guru.

SMP Negeri 3 Harian terletak di Kecamatan Harian-Samosir. Sebagai salah satu sekolah yang memegang tanggung jawab dalam pendidikan, SMP Negeri 3 Harian perlu melakukan berbagai upaya menegakkan disiplin kerja guru melalui peranan maksimal kepala sekolah untuk memanajerial sekolah yang dipimpinnya. Melalui kepemimpinan yang maksimal, dan didukung oleh kegiatan supervisi akademik, diduga disiplin kerja guru SMPN3 Harian akan mencapai tingkat yang maksimal.

Dari ulasan dan tinjauan di atas, maka peneliti tertarik untuk meneliti "Pengaruh Kepemimpinan dan Supervisi Akademik Kepala Sekolah terhadap Disiplin Kerja Guru di SMP Negeri 3 Harian".

\section{Metode Penelitian}

Penelitian kuantitatif ini menggunakan metode survey, dilaksanakan pada bulan Juli 2019 di SMP Negeri 3 Harian, yang terletak di Kecamatan Harian Kabupaten Samosir Provinsi Sumatera Utara. Peneliti melakukan survey mengenai kepemimpinan kepala sekolah dan supervisi akademik di SMPN3. Teknik sampling pada penelitian ini menggunakan sampel jenuh, yakni seluruh guru yang bertugas di SMPN3 Harian sebanyak 15 orang.

Dalam penelitian ini, variable penelitian Kepemimpinan Kepala Sekolah (X1), Supervisi Akademik (X2) dan Disiplin Kerja Guru (X3) merupakan variabel penelitian. Tujuan penelitian ini adalah untuk melihat pengaruh kepemimpinan kepala sekolah dan supervisi akademik terhadap disiplin kerja guru. Teknik Pengumpulan Data menggunakan metode survey, dengan pernyataan-pernyataan survey menggunakan indikator setiap variabel. Sebelum digunakan, instrument penelitian terlebih dahulu diuji validitas dan reliabilitasnya dan dinyatakan telah memenuhi syarat layak digunakan. Untuk mencapai tujuan penelitian tersebut, teknik analisis data yang dipergunakan yaitu analisis korelasional dan kausalitas (pengaruh), dengan menggunakan aplikasi SPSS.22 sebagai alat bantu untuk menganalisis data penelitian yang diperoleh.

\section{Hasil}

Data setiap variabel penelitian dilakukan menggunakan kuisioner survey yang disusun berdasarkan indikator masing-masing variabel. Pengumpulan data variabel Kepemimpinan Kepala Sekolah menggunakan kuisioner Survey Kepemimpinan berisi 25 pertanyaan yang diisi oleh seluruh responden penelitian. Pengumpulan data variabel Supervisi Akademik menggunakan kuisioner Kegiatan Supervisi Akademik Kepala Sekolah berisi 26 pertanyaan yang diisi oleh seluruh 
responden sampel penelitian berjumlah 12 orang, yakni seluruh guru di SMP Negeri 3 Harian Kab. Samosir Sumatera Utara. Pengumpulan data variabel Disiplin Kerja Guru menggunakan kuisioner Survey Disiplin Guru berisi 17 pertanyaan yang diisi oleh Kepala Sekolah.

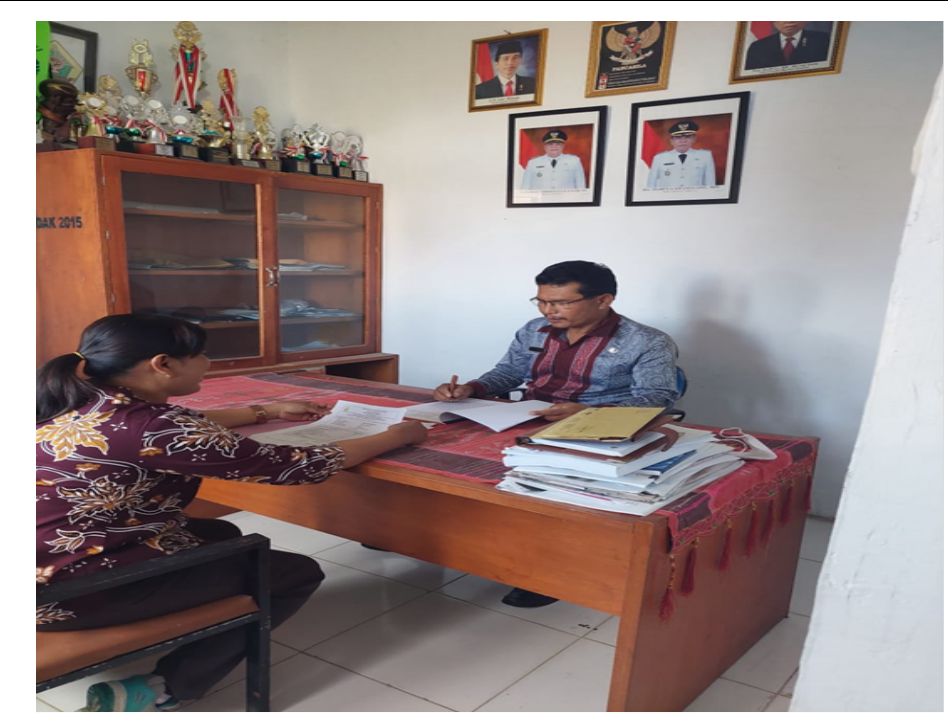

Gambar 2. Kegiatan Supervisi Akademik Kepala Sekolah

Dari hasil survey diperoleh data hasil penelitian yang kemudian dianalisis secara deskriptif sebagai berikut:

Tabel 1. Analisis Deskriptif Variabel Penelitian

Descriptive Statistics

\begin{tabular}{|l|r|r|r|r|r|}
\hline & \multicolumn{1}{|c|}{ N } & Minimum & Maximum & \multicolumn{1}{c|}{ Mean } & Std. Deviation \\
\hline Kepemimpinan & 15 & 83.20 & 92.00 & 87.4667 & 2.55976 \\
Supervisi & 15 & 83.65 & 92.31 & 87.4359 & 2.39605 \\
Disiplin & 15 & 95.00 & 99.00 & 96.8667 & 1.18723 \\
Valid N (listwise) & 15 & & & & \\
\hline
\end{tabular}

Sumber: Olahdata SPSS.

Dari tabel 1 di atas, diperoleh hasil rata-rata skor kepemimpinan kepala sekolah 87,47 berada pada kategori yang sangat tinggi. Dapat dikatakan bahwa seluruh responden memberi nilai yang sangat tinggi pada setiap pernyataan terkait kepemimpinan kepala sekolah. Demikian juga dari rata-rata skor supervisi tergolong pada kategori yang sangat tinggi, responden memberi penilaian yang tinggi pada kegiatan supervisi yang dilakukan kepala sekolah. Selanjutnya pada variabel disiplin kerja guru yang diisi oleh satu orang responden yaitu Kepala Sekolah terhadap 15 orang yang diobservasi, terlihat bahwa rata-rata disiplin kerja berada pada kategori sangat tinggi.

Dari data hasil penelitian atas variabel Kepemimpinan Kepala Sekolah, Supervisi Akademik dan Disiplin Kerja Guru selanjutnya dianalisi pengaruh kepemimpinan dan supervisi Kepala Sekolah terhadap disiplin kerja guru. Sebagai prasayarat sebelum dilakukan analisis pengaruh, terlebih dahulu dilakukan uji normalitas dan uji linearitas. Dengan menggunakan SPSS, diperoleh hasil normalitas dan linearitas sebagai berikut. 
Tabel 2. Uji Normalitas

Tests of Normality

\begin{tabular}{|l|r|r|r|r|r|r|}
\hline & \multicolumn{3}{|c|}{ Kolmogorov-Smirnov $^{\mathrm{a}}$} & \multicolumn{3}{c|}{ Shapiro-Wilk } \\
\cline { 2 - 7 } & Statistic & \multicolumn{1}{c|}{$\mathrm{df}$} & \multicolumn{1}{c|}{ Sig. } & \multicolumn{1}{c|}{ Statistic } & \multicolumn{1}{c|}{ df } & \multicolumn{1}{c|}{ Sig. } \\
\hline Kepemimpinan & .116 & 15 & $.200^{\star}$ & .970 & 15 & .856 \\
Supervisi & .179 & 15 & $.200^{\star}$ & .959 & 15 & .671 \\
\hline
\end{tabular}

*. This is a lower bound of the true significance.

a. Lilliefors Significance Correction

\section{Sumber: Olahdata SPSS}

Tabel 2 menunjukkan hasil uji normalitas, dengan nilai taraf signifikan 0.05 diperoleh sig. 0,2 $>0.05$ pada variabel kepemimpian dan supervisi pada uji Kolmogorov-Smirnov, serta pada uji Shapiro-Wilk nilai sig. $0.856>0.05$ untuk kepemimpinan dan sig.0,671 >0.05 untuk variabel supervisi. Dengan demikian disimpulkan bahwa kedua variabel memiliki sebaran data normal. Selanjutnya prasyarat kedua yang akan dilihat adalah uji linearitas antara variabel kepemimpinan Kepala Sekolah, supervisi terhadap disiplin kerja guru.

Tabel 3. Uji Linearitas

\begin{tabular}{|c|c|c|c|c|c|c|c|}
\hline \multicolumn{8}{|c|}{ ANOVA Table } \\
\hline & & & $\begin{array}{l}\text { Sum of } \\
\text { Squares }\end{array}$ & df & $\begin{array}{l}\text { Mean } \\
\text { Square }\end{array}$ & $\mathrm{F}$ & Sig. \\
\hline \multirow{5}{*}{$\begin{array}{l}\text { Disiplin * } \\
\text { Kepemimpi } \\
\text { nan }\end{array}$} & \multirow{3}{*}{$\begin{array}{l}\text { Betwee } \\
\text { n } \\
\text { Groups }\end{array}$} & (Combined) & 1708.333 & 9 & 189.815 & 1.519 & .336 \\
\hline & & Linearity & 7.752 & 1 & 7.752 & .062 & .813 \\
\hline & & $\begin{array}{l}\text { Deviation } \\
\text { from } \\
\text { Linearity }\end{array}$ & 1700.581 & 8 & 212.573 & 1.701 & .290 \\
\hline & \multicolumn{2}{|c|}{ Within Groups } & 625.000 & 5 & 125.000 & & \\
\hline & \multicolumn{2}{|c|}{ Total } & 2333.333 & 14 & & & \\
\hline \multirow{6}{*}{$\begin{array}{l} \\
\text { Disiplin * } \\
\text { Supervisi }\end{array}$} & \multirow{4}{*}{$\begin{array}{l}\text { Betwee } \\
\text { n } \\
\text { Groups }\end{array}$} & & $\begin{array}{l}\text { Sum of } \\
\text { Squares }\end{array}$ & df & $\begin{array}{l}\text { Mean } \\
\text { Square }\end{array}$ & $\mathrm{F}$ & Sig. \\
\hline & & (Combined) & 1083.333 & 8 & 135.417 & .650 & .721 \\
\hline & & Linearity & 86.401 & 1 & 86.401 & .415 & .543 \\
\hline & & $\begin{array}{l}\text { Deviation } \\
\text { from } \\
\text { Linearity }\end{array}$ & 996.933 & 7 & 142.419 & .684 & .687 \\
\hline & \multicolumn{2}{|c|}{ Within Groups } & 1250.000 & 6 & 208.333 & & \\
\hline & \multicolumn{2}{|l|}{ Total } & 2333.333 & 14 & & & \\
\hline
\end{tabular}

\section{Sumber: Olahdata SPSS}

Tabel 3 di atas menunjukkan hasil uji lineraritas variabel penelitian. Pada tabel linearitas variabel kepemimpinan dan disiplin, diperoleh sig.0,290 $>0.05$ dan pada tabel linearitas variabel supervisi dan disiplin diperoleh nilai sig. 0,687 $>0.05$. Dengan demikian diperoleh hubungan linear kepemimpinan dan supervisi akademis Kepala Sekolah terhadap disiplin kerja guru.

Dari uji normalitas dan liniearitas di atas, diperoleh hasil bahwa prasyarat normalitas dan linearitas dipenuhi. Maka berikutnya dilanjutkan analisis pengaruh 
menggunakan SPSS. Hipotesis penelitian yang pertama diuji adalah pengaruh kepemimpinan Kepala Sekolah terhadap disiplin kerja guru. Dari hasil analisis regresi diperoleh tabel berikut:

Tabel 4. Analisis Pengaruh Kepemimpinan Terhadap Disiplin Kerja

\begin{tabular}{|c|c|c|c|c|c|c|}
\hline \multicolumn{7}{|c|}{ Coefficients $^{a}$} \\
\hline \multirow{2}{*}{\multicolumn{2}{|c|}{ Model }} & \multicolumn{2}{|c|}{ Unstandardized Coefficients } & \multirow{2}{*}{$\begin{array}{c}\begin{array}{c}\text { Standardized } \\
\text { Coefficients }\end{array} \\
\text { Beta } \\
\end{array}$} & \multirow[b]{2}{*}{$\mathrm{t}$} & \multirow[b]{2}{*}{ Sig. } \\
\hline & & B & Std. Error & & & \\
\hline \multirow[t]{2}{*}{1} & (Constant) & 81.102 & 10.371 & & 7.820 & .000 \\
\hline & Kepemimpinan & .180 & .119 & .389 & 1.521 & .152 \\
\hline
\end{tabular}

a. Dependent Variable: Disiplin

\section{Sumber: Olahdata SPSS}

Tabel 4 diatas menunjukkan sig. $0.152>0.05$, artinya hipotesis penelitian ditolak, artinya diperoleh kesimpulan tidak terdapat pengaruh signifikan yang diberikan oleh kepemimpinan Kepala Sekolah terhadap disiplin kerja guru.

Selanjutnya hipotesis penelitian kedua yang diuji adalah ada pengaruh supervisi akademik Kepala Sekolah terhadap disiplin kerja guru. Dengan analisis regresi didapatkan tabel berikut:

Tabel 5. Analisis Pengaruh Supervisi Akademik Terhadap Disiplin Kerja

Coefficients $^{a}$

\begin{tabular}{|c|c|c|c|c|c|c|}
\hline \multirow{2}{*}{\multicolumn{2}{|c|}{ Model }} & \multicolumn{2}{|c|}{ Unstandardized Coefficients } & \multirow{2}{*}{$\begin{array}{c}\begin{array}{c}\text { Standardized } \\
\text { Coefficients }\end{array} \\
\text { Beta }\end{array}$} & \multirow[b]{2}{*}{$t$} & \multirow[b]{2}{*}{ Sig. } \\
\hline & & $\mathrm{B}$ & Std. Error & & & \\
\hline \multirow[t]{2}{*}{1} & (Constant) & 121.064 & 9.971 & & 12.142 & .000 \\
\hline & Supervisi & -.277 & .114 & -.559 & -2.428 & .030 \\
\hline
\end{tabular}

a. Dependent Variable: Disiplin

\section{Sumber: Olahdata SPSS}

Dari deskripsi tabel 5 tampak nilai sig. 0,030<0.05, artinya hipotesis penelitian diterima, yakni terdapat pengaruh signifikan diberikan oleh supervisi Kepala Sekolah terhadap disiplin guru. Hipotesis penelitian ketiga yang diuji adalah kepemimpinan dan supervisi akademik secara bersama-sama memiliki pengaruh signifikan terhadap disiplin kerja guru. Berdasarkan analisis regresi diperoleh tabel sebagai berikut:

Tabel 6. Analisis Pengaruh Kepemimpinan dan Supervisi Akademik Terhadap Disiplin Kerja

ANOVA $^{\text {a }}$

\begin{tabular}{|ll|r|r|r|r|r|}
\hline Model & & \multicolumn{1}{c|}{$\begin{array}{c}\text { Sum of } \\
\text { Squares }\end{array}$} & df & Mean Square & F & Sig. \\
\hline 1 & Regression & 8.036 & 2 & 4.018 & 4.122 & $.043^{\text {b }}$ \\
& Residual & 11.697 & 12 & .975 & & \\
& Total & 19.733 & 14 & & & \\
\hline
\end{tabular}

a. Dependent Variable: Disiplin

b. Predictors: (Constant), Supervisi, Kepemimpinan 


\section{Sumber: Olahdata SPSS}

Tabel 6 diatas menunjukkan sig. 0,043<0.05, artinya hipotesis penelitian diterima yakni terdapat pengaruh signifikan kepemimpinan dan supervisi Kepala Sekolah secara bersama-sama terhadap disiplin kerja guru.

\section{Pembahasan}

Analisis deskriptif pada hasil penelitian di atas menunjukkan bahwa secara umum di SMPN3 Harian para guru sebagai responden menganggap bahwa kepala sekolah memiliki indikator-indikator kepemimpinan yang diharapkan sesuai dengan yang terdapat pada kuisioner. Dengan rata-rata skor yang sangat tinggi yang dipeoleh melalui kuisioner menunjukkan pula bahwa guru di SMPN 3 Harian memberi perhatian terhadap gaya dan pola kepemimpinan kepala sekolah yang memimpin seluruh kegiatan akademik yang ada di sekolah. Selanjutnya dari hasil analisis desktiptif yang menunjukan skor tinggi pada kuisioner supervisi akademik menunjukkan bahwa secara umum guru-guru di SMPN3 Harian menganggap bahwa kepala sekolah telah melaksanakan kegiatan supervisi akademik dengan sangat baik, sesuai dengan indikator supervisi akademik kepala sekolah yang terdapat pada kuisioner. Kemudian dari hasil analisis deskkriptif disiplin kerja guru menunjukkan bahwa guru-guru di SMPN3 Harian memiliki disiplin kerja yang sangat baik sesuai indikator disiplin kerja pada kuisioner.

Pada pengujian hipotesis penelitian pertama, diperoleh hasil bahwa disiplin kerja guru di SMPN3 Harian secara statistik tidak dipengaruhi oleh pola atau gaya kepemimpinan Kepala Sekolah sesuai indikator kepemimpinan Kepala Sekolah. Hal ini bertolak belakang dengan hasil penelitian (Muhammad Rifa'i, 2018) dan (Nurfarhana et al., 2017) yang menemukan bahwa terdapat pengaruh yang signifikan antara kepemimpinan Kepala Sekolah terhadap disiplin kerja guru. Namun perbedaan hasil penelitian ini diduga terjadi karena perbedaan karakteristik guru dan lingkungan sekolah yang diteliti. Di satu sisi kepemimpinan Kepala Sekolah yang dinilai sangat tinggi oleh para guru SMPN3 Harian menunjukkan bahwa pola kepemimpinan Kepala Sekolah menjadi salah satu faktor perhatian guru di lingkungan sekolah. Hal itu sejalan dengan pendapat (Ekosiswoyo, 2007) yang mengatakan bahwa sudah seharusnya kepala sekolah sebagai seorang pemimpin mampu memberdayakan kompetensi guru dalam proses atau kegiatan pembelajaran, menyusun penjadwalan atau agenda kerja yang jelas, membangun relasi antar pribadi yang kuat, adil, efektif, efisien, bertanggung jawab, dan akuntabel, serta bekerja melibatkan semua komponen sekolah termasuk guru di dalamnya.

Pada pengujian hipotesis penelitian kedua, diperoleh hasil bahwa disiplin kerja guru di SMPN3 Harian secara statistik dipengaruhi oleh kegiatan supervisi akademik sesuai indikator supervisi akademik pada kuisioner yang diberikan. Hal ini sejalan dengan hasil penelitian (Suhayati, 2013; Sujadi et al., 2019; Tiswarni, 2019) yang mengatakan bahwa kegiatan supervisi akademik Kepala Sekolah berpengaruh signifikan terhadap disiplin dan kinerja guru. Selain itu juga sejalan dengan kajian teoritis yang dilakukan oleh (Prayoga, 2020) yang menguraikan tentang pentingnya kegiatan supervisi akademik dalam proses manajerial sekolah yang dilakukan oleh kepala sekolah.

Pada pengujian hipotesis penelitian ketiga, diperoleh hasil bahwa jika kepemimpinan Kepala Sekolah dan kegiatan supervisi akademik dilakukan secara 
bersama-sama akan memberikan pengaruh signifikan terhadap disiplin kerja guru di SMPN3 Harian. Pada hipotesis pertama menunjukkan jika hanya melalui satu variabel kepemimpinan Kepala Sekolah saja tidak signifikan berpengaruh terhadap disiplin kerja guru SMPN3 Harian. Namun jika kepemimpinan dilaksanakan bersamaan dengan supervisi akademik oleh Kepala Sekolah, maka akan memberikan pengaruh signifikan terhadap disiplin kerja guru SMPN3 Harian. Hal tersebut menunjukkan bahwa kepala sekolah SMPN3 Harian tidak cukup hanya melaksanakan kegiatan supervisi akademik, namun harus juga bersamaan dengan menunjukkan pola atau gaya kepemimpinan yang baik, agar disiplin kerja guru menunjukkan hasil maksimal.

\section{Kesimpulan}

Dari uraian hasil penelitian dan uraian pembahasan hasil penelitian sebelumnya, maka disimpulkan bahwa secara terpisah kepemimpinan Kepala Sekolah tidak berpengaruh signifikan terhadap disiplin kerja guru namun kegiatan supervisi akademik Kepala Sekolah memberikan pengaruh signifikan terhadap disiplin kerja guru. Hal tersebut terlihat dari hasil uji hipotesis penelitian pertama yang menunjukkan bahwa kepemimpinan kepala sekolah tidak berpengaruh signifikan terhadap disiplin kerja guru di SMP Negeri 3 Harian, sementara uji hipotesis penelitian kedua menunjukkan bahwa supervisi akademik memberikan pengaruh signifikan terhadap disiplin kerja guru di SMP Negeri 3 Harian. Sementara jika secara simultan atau secara bersamaan, terdapat pengaruh signifikan yang diberikan oleh faktor kepemimpinan dan supervisi akademik Kepala Sekolah terhadap disiplin kerja guru. Hal tersebut ditunjukkan oleh hipotesis penelitian ketiga bahwa ketika diuji secara bersamaan, variabel kepemimpinan kepala sekolah dan supervisi akademik kepala sekolah memberikan pengaruh signifikan pada disiplin kerja guru di SMP Negeri 3 Harian.

\section{Daftar Pustaka}

Abd. Rahman. (2014). Peningkatan disiplin kerja guru di sekolah dasar yayasan mutiara gambut. Jurnal Administrasi Pendidikan, 2(1), 1-9. http://ejournal.unp.ac.id/index.php/bahana/article/view/3695/2932

Alhusaini, A., Kristiawan, M., \& Eddy, S. (2020). Pengaruh Motivasi Kerja Dan Disiplin Kerja Terhadap Kinerja Guru. Jurnal Pendidikan Tambusai, 4(3). https://doi.org/10.2139/ssrn.3864629

Ekosiswoyo, R. (2007). Kepemimpinan Kepala Sekolah yang Efektif Kunci Pencapaian Kualitas Pendidikan. Jurnal IImu Pendidikan, 14(2), 76-82. http://journal.um.ac.id/index.php/jip/article/view/24/322

Hadiati, E. (2018). Pengaruh Disiplin Kerja Terhadap Kinerja Guru Mts Se- Kota Bandar Lampung. Al-Idarah: Jurnal Kependidikan Islam, 8(1), 50. https://doi.org/10.24042/alidarah.v8i1.3078

Lumban Gaol, N. T. (2017). Teori dan Implementasi Gaya Kepemimpinan Kepala Sekolah. Kelola: Jurnal Manajemen Pendidikan, 4(2), 213. https://doi.org/10.24246/j.jk.2017.v4.i2.p213-219

Muhammad Rifa'i. (2018). Pengaruh Kepemimpinan Kepala Sekolah Terhadap Disiplin Kerja Guru Di Sd Negeri 060794 Kecamatan Medan Area. Jurnal Manajemen Pendidikan Dan Keislaman, 7(1), 42-50. 
http://jurnal.uinsu.ac.id/index.php/hijri/article/view/1830

Nasution, L., \& Ichsan, R. N. (2020). Gaya Kepemimpinan Kepala Sekolah Terhadap Kinerja Guru. Jurnal Penelitian Pendidikan Sosial Humaniora, 5(2), 78-86. https://jurnal-Ip2m.umnaw.ac.id/index.php/JP2SH/article/view/473

Nugraheni, A. S., \& Rahmayanti, R. (2016). Pengaruh Disiplin Kerja Terhadap Kinerja Guru di MI Al Islam Tempel dan MI Al Ihsan Medari. Jurnal Pendidikan Madrasah, 1(November), 277-294.

Nurfarhana, A., Abdillah, A., \& Prasetyono, H. (2017). Faktor Yang Berpengaruh Terhadap Disiplin Kerja Guru SMKN 1 DEPOK dan SMKS YAPAN Indonesia. Research and Development Journal of Education, 4(1), 23-43.

Prayoga, A. (2020). Supervisi Akademik Kepala Madrasah. Inovatif, 6(1), 105-124.

Purwanti, S. (2013). Peran Kepemimpinan Kepala Sekolah Dalam Meningkatkan Disiplin Kerja Guru Dan Pegawai Di SMA Bakti Sejahtera Kecamatan Kongbeng Kabupaten Kutai Timur. EJournal Administrasi Negara, 1(1), 210224. http://ejournal.an.fisip-unmul.ac.id/site/wp-content/uploads/2013/03/jurnal ajeng genap (03-04-13-12-01-42).pdf [accessed: November 7, 2013]

Rusmawati, V. (2013). Peran Kepemimpinan Kepala Sekolah dalam Upaya Meningkatkan Disiplin Kerja Guru pada SDN 018 Balikpapan. EJournal Administrasi Negara, 1(2), 395-409.

Said, A. (2018). Kepemimpinan Kepala Sekolah Dalam Melestarikan Budaya Mutu Sekolah Akhmad. 2(1).

Salim, N. A. (2016). Kepemimpinan Kepala Sekolah dalam Bentuk Motivasi Kerja Guru. Jurnal Pendas Mahakam, 1(1), 69-79.

Sola, E. (2019). Supervisi Akademik versus Kualitas Pembelajaran. Jurnal Idaarah, III(1), 148-154.

Suginam, A. (2019). Upaya Meningkatkan Kompetensi Guru Kelas Dalam Proses Pembelajaran Melalui Supervisi Akademik di SD Negeri 4 Mataram. Jurnal Paedagogy, 6(2), 41-48.

Suhayati, I. (2013). Supervisi Akademik Kepala Sekolah, Budaya Sekolah Dan Kinerja Mengajar Guru. Jurnal Administrasi Pendidikan, 17(1), 86-95. https://doi.org/10.17509/jap.v17i1.6435

Sujadi, E., Odha Meditamar, M., Wahab, M., \& Putri Utama, R. (2019). Pengaruh Supervisi Kepala Sekolah Terhadap Kinerja Mengajar Guru. Jurnal Literasiologi, 1(2), 11. https://doi.org/10.47783/literasiologi.v1i2.16

Tiswarni, T. (2019). Usaha Kepala Sekolah Dalam Meningkatkan Disiplin Kerja Guru (Studi Deskriptif Kualitatif di SMP N 1 Argamakmur Kabupaten Bengkulu utara). At-Ta'lim: Media Informasi Pendidikan Islam, 18(1), 261. https://doi.org/10.29300/attalim.v18i1.1650

Yuliandri, J., \& Kristiawan, M. (2016). Peran Kepemimpinan Kepala Sekolah Terhadap Peningkatan Kinerja Guru. Prosiding Seminar Nasional Pendidikan: Mewujudkan Sumber Daya Manusia Yang Profesional Dalam Kompetisi Global, 570-577. https://doi.org/10.31219/osf.io/k28p5 